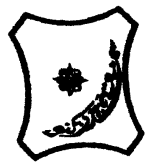

Bayero Journal of Pure and Applied Sciences, 9(1): 213 - 216

Received: March, 2016

Accepted: May, 2016

ISSN $2006-6996$

\title{
HEAVY METAL POLLUTION ASSESSMENT IN THE SEDIMENTS OF LAKE CHAD, NIGERIAN SECTOR
}

\author{
Jonathan, B.Y., Maina, H.M and Maitera, O. N. \\ Department of Chemistry Modibbo Adama University of Technology, Yola, P.M.B 1076 Yola Adamawa State. \\ Berny2025@yahoo.com
}

\begin{abstract}
Sediments were collected from Dumba and KwataYobe of Lake Chad, Nigerian Sector.The aim was to assess the pollution statusof the sediments of the lake. The concentration of heavy metals, Cadmium (Cd), Chromium (Cr), Copper (Cu), Iron (Fe), Manganese (Mn), Nickel (Ni), lead (Pb), Zinc (Zn) and Arsenic (As) were analysed using energy dispersive $x$-ray fluorescence (EDXRF). The mean concentration of heavy metals varies between 0.01 to $80877.06 \pm 10.12 \mathrm{mg} / \mathrm{kg}$, were compared with standard average shale to assess the pollution status of the sediments. The degree of pollution in Dumba and KwataYobe sediments for $\mathrm{Cd}, \mathrm{Cr}, \mathrm{Cu}, \mathrm{Fe}, \mathrm{Mn}, \mathrm{Ni}, \mathrm{Pb}, \mathrm{Zn}$ and As was assessed using geo-accumulation index (Igeo). The results indicated that the sediments have been polluted with $\mathrm{Cd}, \mathrm{Cr}, \mathrm{Fe}, \mathrm{Mn}, \mathrm{Pb}, \mathrm{Zn}$ and As. The Igeo values for $\mathrm{Cd}, \mathrm{Cr}, \mathrm{Cu}, \mathrm{Fe}, \mathrm{Mn}, \mathrm{Ni}$ and $\mathrm{Zn}$ at KwataYobevaries between 0.007 to 0.630 , indicating unpolluted sediments, while Igeo values for $C d$ at Dumba and $P b$ in both sites varies between $1.002+01.550$ indicating moderately polluted sediments.Igeo values for As varies between 10.411 to 13.20 in both sites indicating very highly polluted sediments. The Igeo values for Cd at Dumba, Pb and As in both sites indicated that the sediments were polluted.
\end{abstract}

Keywords:Assessment,Average shale, Geo-accumulation index, Heavy metal pollution, Sediments.

\section{INTRODUCTION}

Lake Chad is one of the largest natural lakes in the world. It extends to four African countries of Chad, Niger, Cameroon and Nigeria. The Chari River in Cameroon provides over $90 \%$ of Lake Chad's waters. Lake Chad is shallow and remains freshwaters lake (UNEP, 2007).Heavy metals are one of the serious pollutants in our natural environment because of their toxicity, persistence bioaccumulation and biomagnifications in food chain (Ozturk, et al., 2009; Censiet al., 2006). Heavy metals are usually present at low concentrations in aquatic environments but deposits of anthropogenic origin have raised their concentrations, causing environmental problems in lakes (Ntakirutimanaet al., 2013). Theheavy metals enter the aquatic environment from both natural sources, such as rock weathering, soil erosion and the dissolution of water-soluble salts and anthropogenic sources such as agricultural activities, and residential and industrial waste products (Forstner and Wittman, 1981).When heavy metals enter the environment, they are distributed between the aqueous phase and the suspended sediments during their transport. Heavy metals are non-biodegradable; they are not removed from water as a result of self purification. Once they are discharged into water bodies, they are adsorbed on sediment particles, accumulate in lakes, rivers and enter the food chain (Loska and Wiechula, 2003).

Sediments, as basic components of the aquatic environment, play an important role in elemental cycling and they are responsible for transporting a significant amount of pollutants and nutrients. They serve as important sinks for various pollutants such as heavy metals and pesticides. Aquatic sediment accumulates persistent and toxic chemicals to levels many times higher than the water Colum concentration (Milenkovicet al., 2005). Heavy metals tend to be assimilated in sediment with organic matter, Fe/Mn oxides, sulphide, and clay thereby forming several reactive components, which are harmful to the environment. Hence, sediment is always regarded as the potential reservoir for heavy metals and plays an important role in adsorption of dissolved heavy metals (Praveenaet al, 2010). Under different physical and chemical conditions, heavy metals in sediment may leach out into the water column as free ions. In turn, polluted sediments also act as sources of heavy metals when released into the lake or river water. Heavy metals concentration in lake or river water can be regarded as a good indicator of the lake or river pollution.(Praveenaet al, 2010). Polluted sediments can threaten biota in the benthic environment, exposing them to hazardous concentration of toxic heavy metals. Some kinds of toxic sediments kill benthic organisms, reducing the food available to larger animals such as fish (Abidaet $a /, 2009)$. Geo-accumulation index $\left(\mathrm{I}_{\mathrm{geo}}\right)$ was used to assess heavy metals accumulation in sediments as introduced by Muller (1969) to measure the degree of heavy metals pollution in aquatic sediments (Chakravarty and Patgiri, 2009).

The objectives of this study were to determine the concentrations of $\mathrm{Cd}, \mathrm{Cr}, \mathrm{Cu}, \mathrm{Fe}, \mathrm{Mn}, \mathrm{Ni}, \mathrm{Pb}, \mathrm{Zn}$ and As in the sediments and the pollution status of Lake Chad, Nigerian Sector. 


\section{MATERIALS AND METHODS}

This study was carried out at Baga, Nigerian sector of the Lake Chad. Baga is in Kukawa Local Government Area of Borno State. It lies on latitude $12^{\circ} 55^{\prime}$ and longitude $13^{\circ} 35^{\prime} \mathrm{E}$. The major economic activities of the population in Baga are agriculture, stock breeding and fishing. The sampling sites are Dumba and KwataYobe.

The geo-accumulation index $\left(\mathrm{I}_{\mathrm{geo}}\right)$ was calculated using the formula Igeo $=\log _{2}\left(\frac{C_{n}}{1.5 B}\right)$

(Müller, 1969).Where, $C_{n}$ is the measured concentration of heavy metal in sediments, $B_{n}$ is the geochemical background concentration of the elements and 1.5 is the background matrix correction due to terrigeous effects. The $I_{g e o}$ classification consists of seven Classes(0-6), ranging from background concentration to very heavily polluted: less than zero, $<0$ (Class 0 ) is background concentration, $0-1$ (Class 1 ) is unpolluted to moderately polluted sediments, $1-2$ (Class 2) is moderately polluted, 2-3 (Class 3 ) is high pollution, 34 (Class 4 ) is heavily polluted, 4-5 (Class 5 ) is highly to very heavily polluted, 5-6 (Class 6 ) is very heavily polluted (Kumar and Edward, 2009).

Sediment Sampling and Sample Preparation for the determination of Heavy Metal

Sediment samples were collected between January, 2012 and March, 2012 using hand trowel $(10-20 \mathrm{~cm})$. The samples collected were placed in polyethylene bag and were transported to the laboratory for further analysis. A modified version of emission-transmission (E-T) method (Kump, 1996: Angeyoet al, (1998) and Funtua, (1999) was used to analyzed the sample. A quantity of $1.00 \mathrm{~kg}$ of the sediments was air-dried until a constant weight was obtained. It was then ground to powder with a mortar and pestle to grain size less than $125 \mu \mathrm{m}$ and was homogenized by it, because metals are known to adhere to fine particles. A quantity of $0.5 \mathrm{~g}$ of powdered sediments samples were mixed with three drops of liquid organic binders, polyvinyl chloride (PVC) and were pressed with 10 tons hydraulic press to produce pellets of $19 \mathrm{~mm}$ diameter. Three replicates of pellets of the sample were prepared. The resulting pellets were used to analyse the heavy metals in the samples. Pellets of sediment was put into the $x$-ray fluorescence spectrometer sample holder and was bombarded with ${ }^{109} \mathrm{Cd}$ as the excitation source that emits $\mathrm{Ag}-\mathrm{K}$ x-rays (22.1kev) in which case all the elements with lower characteristic excitation energies were accessible for detection in the sample. Fluorescent $x$-rays was produced which passes to the $\mathrm{Si}$ (Li) detector, through Mo target. The intensity of the fluorescent $x-$ rays on the detector is proportional to the concentration of the individual element of interest in the sample.

Map of Lake Chad, Nigerian Sector and Surrounding Regions was presented in Figure 1.

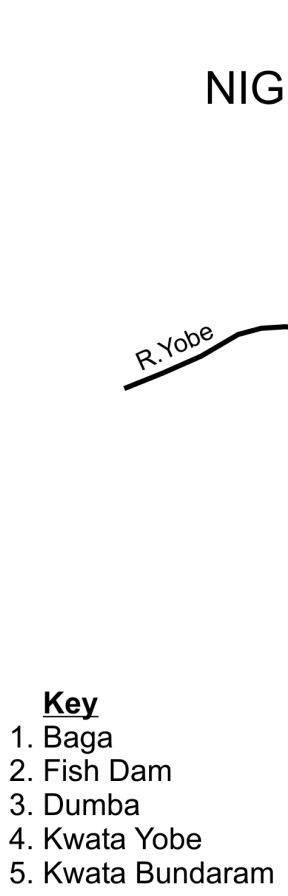

Fig. 3.1: Map showing location of sampling area in Lack Chad, at Baga Nigerian Portion (Source: World Lake Database, 1983)

Figure 1: Map of Lake Chad, NigerianSector Indicating Sampling Sites and Surrounding Regions (Source: World Lake Datbase, 1983) 


\section{STATISTICAL ANALYSIS}

Mean heavy metal concentrations and standards deviations were used to explain the results.

\section{RESULTS FOR HEAVY METALS IN SEDIMENTS}

The mean heavy metal concentrations in Dumba and KwataYobe sediments ranged between 0.01 to $3.64 \pm$ $0.13 \mathrm{mg} / \mathrm{kgCd} ; 66.07 \pm 5.80$ to $98.75 \pm 0.25 \mathrm{mg} / \mathrm{kgCr}$; $19.35 \pm 5.01$ to $19.39 \pm 3.03 \mathrm{mg} / \mathrm{kgCu} ; 44327.94 \pm$ 8.80 to $80877.06 \pm 10.12 \mathrm{mg} / \mathrm{kg} \mathrm{Fe} ; 1167.12 \pm 10.15$ to $1247.06 \pm 10.12 \mathrm{mg} / \mathrm{kg} \mathrm{Mn;} 31.42 \pm 2.03$ to 45.25 $\pm 4.77 \mathrm{mg} / \mathrm{kg} \mathrm{Ni} ; \quad 100.23 \pm 10.23$ to $126.83 \quad \pm$ $10.24 \mathrm{mg} / \mathrm{kg} \mathrm{Pb} ; 101.13 \pm 10.55$ to 148.94 $\pm 13.62 \mathrm{mg} / \mathrm{kg} \mathrm{Zn}$ and $674.90 \pm 15.18$ to $858.06 \pm$ $20.06 \mathrm{mg} / \mathrm{kg}$ As. $\mathrm{Cd}$ and $\mathrm{Cr}$ at Dumba, Fe at KwataYobe, $\mathrm{Mn}, \mathrm{Pb}, \mathrm{Zn}$ and As concentrations in both sites were highest. $\mathrm{Cd}$ at KwataYobe, $\mathrm{Cu}$ in both sites, Fe at Dumba, Ni concentrations in both sites were lowest when compared to the standard average shale as presented in Table1.

Table 1: Mean Concentration $(\mathrm{mg} / \mathrm{kg})$ of Heavy Metal in Sediments of Lake Chad, Nigerian Sector and their Average Shale.

\begin{tabular}{|c|c|c|c|c|c|c|c|c|c|}
\hline \multirow{2}{*}{$\begin{array}{l}\text { Sampling } \\
\text { Sites }\end{array}$} & & & & Heavy & \multicolumn{5}{|c|}{ Metals(mg/kg) } \\
\hline & $\mathrm{Cd}$ & $\mathrm{Cr}$ & $\mathrm{Cu}$ & $\mathrm{Fe}$ & $\mathrm{Mn}$ & $\mathrm{Ni}$ & $\mathrm{Pb}$ & $\mathrm{Zn}$ & As \\
\hline Dumba & $\begin{array}{c}3.64 \\
\pm \\
0.13\end{array}$ & $\begin{array}{c}98.75 \\
\pm \\
0.25\end{array}$ & $\begin{array}{c}19.39 \\
\pm \\
3.03\end{array}$ & $\begin{array}{c}44327.94 \\
\pm \\
880\end{array}$ & $\begin{array}{c}1167.12 \\
\pm \\
10.15\end{array}$ & $\begin{array}{c}45.25 \\
\pm \\
477\end{array}$ & $\begin{array}{c}126.83 \\
\pm \\
10.24\end{array}$ & $\begin{array}{c}148.94 \\
\pm \\
13.62\end{array}$ & $\begin{array}{c}674.90 \\
\pm \\
15.18\end{array}$ \\
\hline KwataYobe & 0.01 & $\begin{array}{c}66.07 \\
\pm \\
5.80\end{array}$ & $\begin{array}{c}19.35 \\
\pm \\
5.01\end{array}$ & $\begin{array}{c}80877.06 \\
\pm \\
10.12\end{array}$ & $\begin{array}{c}1249.06 \\
\pm \\
10.12\end{array}$ & $\begin{array}{c}31.42 \\
\pm \\
2.03\end{array}$ & $\begin{array}{c}100.23 \\
\pm \\
10.23\end{array}$ & $\begin{array}{c}101.13 \\
\pm \\
10.55\end{array}$ & $\begin{array}{c}858.06 \\
\pm \\
20.06\end{array}$ \\
\hline $\begin{array}{l}\text { Average } \\
\text { Shale }\end{array}$ & 0.3 & 90.00 & 45.00 & $46,000.00$ & 850.00 & 68.00 & 20.00 & 95.00 & 13.00 \\
\hline
\end{tabular}

Values are mean \pm Standard Deviation Average Shale, World geochemical background Concentration

\section{DISCUSSION}

The results indicated that heavy metal pollution can be assessed with respect to average shale which was widely used (Harikumaret al., 2009). In this study average shale was used as a standard in comparison of the mean concentration of heavy metals in the core sediments (Table 1) (Ong and Kamaruzzaman, 2009), which indicates that all the sites were heavily polluted with $\mathrm{As}$ and $\mathrm{Pb}$. Fe was heavily polluted at KwataYobe and $\mathrm{Cd}$ at Dumba. $\mathrm{Cr}$ was moderately polluted at Dumba, while $\mathrm{Mn}$ at both sites. $\mathrm{Cd}$ and $\mathrm{Cr}$ at KwataYobe were unpolluted, and $\mathrm{Fe}$ at Dumba. $\mathrm{Cu}$ and $\mathrm{Ni}$ in both sites were unpolluted and $\mathrm{Zn}$ was moderately polluted in both sites. The high mean concentration of heavy metals in sediments can often be attributed to terrigenous input and anthropogenic influences. It can be a good indication of man-induced pollution (Mohammed, 2005).

Heavy metals are widespread and persistent in aquatic ecosystem, potentially toxic, and can be accumulated in food web. Industrial and agricultural activities and atmospheric deposition are some of the many way through which sediments are found to have been polluted(Tanget al, 2014a).Economic development and population growth also influence the distribution of heavy metals in the sediments; heavy metals in the sediments can accumulate relatively large amounts in aquatic organisms such as fish, resulting in a threat to human health (Tanget al, 2014b).

\section{RESULTS FOR THE DEGREE OF POLLUTION IN SEDIMENTS}

The degree of pollution in sediments can be assessed further by indices such as geo-accumulation. Igeo values was based on $C_{n}$, the measured concentration of heavy metals in sediments using $X$-ray fluorescence to $_{n}$, the geochemical background concentration of the elements (average shale), that is the international standards of each elements of the background and 1.5 is the background matrix correction due to terrigeous effects. Igeo values have no units, it is a ratio. The average shale was presented in Table 2. The Igeo values of $\mathrm{Cd}, \mathrm{Cr}, \mathrm{Cu}, \mathrm{Fe}, \mathrm{Mn}, \mathrm{Ni}$, $\mathrm{Pb}, \mathrm{Zn}$ and As varies between 0.007 to $1.55 \mathrm{Cd}, 0.147$ $+00.150 \mathrm{Cr}, 0.086 \mathrm{Cu}, 0.195+00.353 \mathrm{Fe}, 0.293$ to $0.630 \mathrm{Mn}, 0.092$ to $0.133 \mathrm{Ni}, 1.002$ to $1.275 \mathrm{~Pb}, 0.213$ to $0.314 \mathrm{Zn}$ and 10.411 to $13.200 \mathrm{As}$, and the results was presented in Table 2

Table 2: Sediments Geoaccumulation Index of the Heavy Metals from Lake Chad, Baga, Nigerian Sector.

\begin{tabular}{llllllllll}
\hline Sampling Sites & $\mathrm{Cd}$ & $\mathrm{Cr}$ & $\mathrm{Cu}$ & $\mathrm{Fe}$ & $\mathrm{Mn}$ & $\mathrm{Ni}$ & $\mathrm{Pb}$ & $\mathrm{Zn}$ & $\mathrm{As}$ \\
\hline Dumba & 1.55 & 0.150 & 0.086 & 0.195 & 0.630 & 0.133 & 1.275 & 0.314 & 10.411 \\
KwataYobe & 0.007 & 0.147 & 0.086 & 0.353 & 0.293 & 0.092 & 1.002 & 0.213 & 13.20 \\
*Average Shale & 0.30 & 90.00 & 45 & 46000 & 850 & 68 & 20 & 95 & 13 \\
\hline
\end{tabular}

Average Shale, World geochemical background Concentration

Turekian and Wedepohl (1961) 


\section{DISCUSSION}

The Igeo values of $\mathrm{Cr}, \mathrm{Cu}, \mathrm{Fe}, \mathrm{Mn}, \mathrm{Ni}$ and $\mathrm{Zn}$ in both sites fall in class 1 , indicating unpolluted to moderately polluted sediments. Cd at Dumba and $\mathrm{Pb}$ in both sites are moderately polluted sediments. As in both sites are very heavily polluted sediments. The moderately and the very heavily polluted sediments are attributed principally to anthropogenic activities such as agricultural practices, industrial effluents, vehicular emission and terrigenous influx. These results suggest that a significant portion of the heavy metals originated from anthropogenic sources. The Igeo values give the advantage of not aggregating all the pollutants into one value and therefore treating each heavy metal independently, giving a good picture of the extent of individual heavy metal pollution. The assessment of natural background concentrations of each heavy metal is to provide the exact identification of anthropogenic sources.

\section{REFERENCES}

Abida, B..HariKrishna, S and Irfanulla, K.(2009). Analysis of Heavy Metals in Water, Sediments and Fish samples of Madivala Lakes of Bangalore, Karnataka.International Journal of Chem. Tech Research 1(2): 245-249.

Angeyo, K. H., Patel. P.,MangalaJ. Mand Naroya, D. G. S (1998). Optimization of X-ray fluorescence elemental analysis an example from Kenyan. Appl. Rod. Isot., 49: 885- 891.

Censi, P., Spoto, S., Saiano.F.Sprovieri.M..Mazzola, S., Nardone. G., Di Geronimo, S. T.,Punturo.R and Otlonello, D., (2006). Heavy Metal in coastal water system. A case studyfrom the Nonhwestern Gulf of Thailand. Chemosphere.64: 1167-1176.

Chakravarty and Patgiri, 2009. M. Chakravarty, A.D. Patgiri. Metal pollution assessment in sediments of the DikrongRiver, N.E. India. J. Hum. Ecol., 27 (1) (2009), pp. 63-67

Forstner, U. and Wittman, G (1981). Metal Pollution in the aquatic environment. Berlin, Heidelberg. Germany: Springer-Verlog272, pp486

Funtua. 1. I. (1999). Application of the TransmissionEmissionmethod in KDXRF, or the Determination of Trace Elements in Geological and Biological materials, J. Trace Microprobe Tech. 17: 293-297.

Harikumar, P.S., Nasir, U.P and MujeebuRahman, M.P. (2009) Distribution of heavy metals inthe core sediments of a tropical wetland system. Int. J. Environ. Sci. Tech. 6(2): 225-232

Kumar, S. P and Edward, J. K (2009). Assessment of metal concentration in Sediment Cores ofManakudy estuary, South West of India. Indian, J. Mar. Sci. 38(2), 235-248

Kump. P. (1996). Quantitative Analyses of Environmental Samples (QAES). Instruction Manual, Ljubljana.

Loska and Wiechula(2003).Wiechula.Application of principal component analysis for the estimation of source heavy metal contamination in surface sedimentsfrom Rybnik ReservoirChemosphere, 51, pp. 723-733

Milenkovic, N., Damjanaovic. M and Ristic, M (2005). Heavy Metal Pollution in Sediments from the

\section{CONCLUSION}

The results of this study provide valuable information about some heavy metal concentrations in the sediments of Lake Chad, Nigerian Sector. The sediments in Dumba and KwataYobehave accumulated heavy metals from the surrounding environment. The Igeo values indicated widespread pollution by $\mathrm{Pb}$ and As.

\section{Recommendations}

I recommend that this research should be carried out on farm lands.

\section{Acknowledgements}

I am grateful to Prof. H.M Mainamy supervisor and Dr.O. N.Maiteramy internal examiner. I carried out the research, and Iam delighted for their support and encouragement. I would like to thank the laboratory technologist at centre for Energy Research and Training Zaria for analyzing the samples.

Iron Co, Serbia and Montenegro. Polish Journal of Environmental Studies 16(6) 781 -787.

Mohammed, A.W (2005). Geochemistry and sedimentology of core sediments and the coast, Egypt. Egypt J. Aquat Res, 31(1): 92-103

Müller G. (1969). Index of geoaccumulation in sediments of the Rhine River. Geojournal 2, 108-118

Ntakirutimana, G. Du, J.S. Guo, XuGao, Lei Huang (2013). Pollution and potential ecologicalrisk assessment of heavy metals in a lake.Pol. J. Environ. Stud., 22 (4) pp. 1129-113

Ong, M. C and Kamaruzzaman, B. Y (2009). An assessment of metal $(\mathrm{Pb}$ and $\mathrm{Cu}$ ) contamination in bottom sediments from South China Sea coastal water, Malaysia. Am. J. App. Sci. 6(7) 1418-1423

ÖztÜrk, M., Ozozen, G., Minareci, O and Minareci, E. (2009). Determination of Heavy Metals in fish.Water and Sediments of Avsar Dam Lake in Turkey, Health Sci. Eng. 6(2): 73-80.

Praveena, M.., Aris, A. Z. and Radojevic, M (2010.). Heavy metals dyanamics and source in intertidal mangrove sediment of Sabah, Borneo Island. EnvironmentAsia, vol. 3, pp. 79-83

Tang W. Z., Ao L., Zhang $H$. and Shan B. Q (2014a). Accumulation and risk of heavy metals in relation to agricultural intensification in the river sediments of agricultural regions. Environ. Earth Sci. 71, 3945-3951.

Tang W., Cui J., Shan B., Wang, C and Zhang W (2014b).. Heavy Metal Accumulation by Periphyton Is Related to Eutrophication in the Hai River Basin, Northern China. 1(9), e86458 PMC free article] [PubMed

Turekian, N. K. and Wedepohl, K. H. (1961) Distribution of the elements in some major units of the earth's crust. Geological Society of America Bulletin, 72: 175-191.

United Nations Environment Programme (2007). Atlas of our Changing Environment World Lake Database, (1983).Lake Chad.Interactional Lake Environment Committee 